\title{
An Assessment of the Effect of Industrial and Sewage Effluent on Aquatic Invertebrates: A Case Study of A Southern Urban Stream, Zimbabwe
}

\author{
Dube Trevor (Corresponding author) \\ Department of Biological Sciences, Midlands State University, P. Bag 9055, Gweru, Zimbabwe \\ Tel:263 -54-260-568 ext 332 E-mail: tdube@msu.ac.zw \\ Makaka Caston \\ Department of Biological Sciences, Midlands State University, P. Bag 9055, Gweru, Zimbabwe \\ Tel:263-54-260-568 ext 340 E-mail: makakac@msu.ac.zw \\ Sibanda Zwelabo \\ Department of Biological Sciences, Midlands State University, P. Bag 9055, Gweru, Zimbabwe \\ Tel: 263-54-260-568 ext 340 E-mail: zwenilabo@yahoo.com
}

\begin{abstract}
The impact of industrial effluent discharged in Mazai stream was assessed through physical-chemical parameters and also by bio-monitoring of benthic macro-invertebrates. Samples were collected at three sites, one before the effluent discharge point into the stream (site 3) and two sites which were located downstream after the discharge points (sites 1 and 2). High levels of chemical pollutants were recorded at sites 1 and 2 (ZINWA red category) whereas site 3 (reference site) consisted of relatively clean water (ZINWA blue category). This was confirmed by the biological evaluation process. The SASS4 scores at sites 1 and 2 indicated a deterioration of water quality while site 3 there was good water quality with high species diversity. Detrended correspondence analysis (DCA) showed that pollution sensitive taxa such as Hemiptera, Trichoptera, Coleoptera and Odonata were dominant at site 3 whilst the other sites were dominated by pollution tolerant species such Chironomids. Continuous discharge of effluent could lead to extreme degradation of Mazai stream hence loss of biodiversity of macro-invertebrates.
\end{abstract}

Keywords: Stream, Macro invertebrates, Sewage effluent, Bio-monitoring, Water quality

\section{Introduction}

Water pollution is a major problem in the global context. The problem of water pollution is being experienced by both developing and developed countries. Sewage disposal is of major concern in most urban areas of Zimbabwe. Wastewater from industries and sewage spillages from burst pipes around the country are released into streams and rivers which finally discharge into dams around the cities of Zimbabwe. With the prevailing hard economic situation in the country, most of the trade waste effluents are released into the environment untreated or partially treated. Industrialists have adopted the use of substandard treatment methods that partially treat and in some instances, forego the effluent treatment process. At Thorngrove sewage works, Zimbabwe, raw sewage is at times discharged into Mazai stream to avoid plant clogging when power cuts are experienced. The same problem is experienced in Lake Chivero catchment where raw sewage is finding its way into Manyame, Marimba and Mukuvisi rivers, the tributaries of the lake leading to its eutrophication (Moyo, 1997). The result is an increase in organic pollutant loads hence increased algal growth that greatly affects aquatic invertebrate diversity (Chutter, 1972).

Most studies on water quality in Zimbabwe have been concerned with assessing the physico-chemical parameters of water (Mathuthu et al., 1997; Moyo and Worster, 1997, Magadza, 2003, Ndebele, 2009). This study investigates the diversity of aquatic invertebrates in relation to pollutant levels in Mazai stream, a tributary of Umguza dam in Bulawayo.

\section{Materials and Methods}

The study was conducted in Mazai stream of Bulawayo, Zimbabwe. The stream runs from Donnington industrial area past Belmont, Steeldale, Thorngrove industrial areas and finally past Thorngrove sewage works effluent discharge point (Figure 1). The stream eventually drains into Umguza dam. Water from Umguza dam is mainly used for capture fisheries by locals and irrigation purposes by Ingwebu farm. Three sampling sites were selected along the stream. Site 1 was at Khami Road Bridge, a point where industrial effluent is discharged into the stream. Site 2 was downstream about $90 \mathrm{~m}$ away from the sewage discharge point at Thorngrove sewage works and site 3 upstream of Mazai stream, before industrial waste and sewage discharge points (figure 1). This was taken as a reference point with relatively clean water.

Water samples were collected over a period of six months from April 2009 to October 2009. Sampling was done once each month. Two replicate samples were collected for each parameter and the mean results calculated. Samples for chemical analysis, nitrates, phosphates, permanganate value and ammonia were collected into 1000 
$\mathrm{ml}$ water bottles and refrigerated at low temperatures $\left(<4^{\circ} \mathrm{C}\right)$ prior to laboratory analysis. Temperature readings were recorded at the sampling sites using a mercury bulb thermometer. A Mettler Toledo $320 \mathrm{pH}$ meter was used to measure $\mathrm{pH}$. A Mettler Toledo MC 226 conductivity meter was used to measure conductivity. Total nitrogen and total phosphorus concentrations were determined in the laboratory with Hach nutrient analysis kits and a Hach spectrophotometer (DR010 Hach Co., Loveland, Colorado, USA). Turbidity levels were measured in Nephelometric units (NTUs) using the HACH 2100A turbidity meter. Macro-invertabrates were collected using the kick sampling method at each site (Chutter, 1994). Samples for aquatic invertebrates were collected into collecting bottles and preserved using 10 percent buffered Formalin.

\subsection{Data Analysis}

Analysis of variance (ANOVA) was used to compare the physical and chemical parameters amongst the three sites. The South African Scoring System (SASS4) was used as a biotic index for evaluating the river ecosystem health (Chutter, 1998). Shannon-Weiner index was used to evaluate abundance and evenness of macro-invertebrates amongst the three sites. Species occurrences were ordinated using PAST version 1.95 (Past 1999- 2009). Detrended correspondence analysis (DCA) was used to examine possible gradients in species composition (Hill \& Gauch, 1980).

\section{Results}

\subsection{Chemical parameters of water from Mazai stream}

The levels of ammonia decreased from site 1 to site $3(\mathrm{~S} 1>\mathrm{S} 2>\mathrm{S} 3)$ (Table 1). There were significant differences in the levels of ammonia amongst the three sites (ANOVA, $\mathrm{F}_{(2,6)}=27.00<\mathrm{F}_{\mathrm{c}}=134.4, \mathrm{p}=0.001$ ). This was also true for phosphates (ANOVA, $\mathrm{F}_{(2,6)}=5.14<\mathrm{F}_{\mathrm{c}}=6.167, \mathrm{p}=0.05$ ). This trend also applied for permanganate value (PV) (Table 1). Site 1 had $63.3 \mathrm{mgL}^{-1}$ whereas sites 2 and 3 were 36 and $4 \mathrm{mgL}^{-1}$ respectively (ANOVA, $\mathrm{F}_{(2,6)}=27.0<\mathrm{F}_{\mathrm{c}}=57.743, \mathrm{p}=0.001$ ). However the levels of nitrates were slightly higher at site 2 than sites 1 and $3(\mathrm{~S} 2>\mathrm{S} 1>\mathrm{S} 3)$. There were no significant differences in the levels of nitrates amongst the sites (ANOVA, $\mathrm{F}_{(2,6)}=5.14>\mathrm{F}_{\mathrm{c}}=3.66, \mathrm{p}=0.05$ ).

The mean values for all chemical parameters in sites 1 and 2 fell under the Zimbabwe National Water Authority (ZINWA) Red category (range; $\leq 40 \mathrm{mgL}^{-1}$ for $\mathrm{PV}, \leq 5 \mathrm{mgL}^{-1}$ for phosphates and $\leq 2 \mathrm{mgL}^{-1}$ for ammonia) whilst those from site 3 comply with the Blue permit range $\left(\leq 0.5 \mathrm{mgL}^{-1}\right.$ for ammonia, $\leq 3 \mathrm{mgL}^{-1}$ for nitrates, $\leq 0.5$ $\mathrm{mgL}^{-1}$ for phosphates and $\leq 5 \mathrm{mgL}^{-1}$ for PV). The Red category denotes high hazard or bad water quality whilst the blue category denotes safe water or good water quality.

Conductivity levels decreased from site 1 to site $3(\mathrm{~S} 1>\mathrm{S} 2>\mathrm{S} 3)$ (Table 1). There were significant differences in the conductivity levels amongst the three sampling sites (ANOVA, $\left.\mathrm{F}_{(2,6)}=27.0<40.391, \mathrm{p}=0.001\right)$. However the $\mathrm{pH}$ and temperature levels were slightly higher at site 2 than sites 1 and $3(\mathrm{~S} 2>\mathrm{S} 3>\mathrm{S} 1)$. There was no significant difference in $\mathrm{pH}$ levels amongst the sampling sites (ANOVA, $\mathrm{F}_{(2,6)}=5.14>\mathrm{F}_{\mathrm{c}}=4.926, \mathrm{p}=0.05$ ). $\mathrm{pH}$ levels were slightly acidic (6.8) at site 1 but slightly alkaline (7.3) at site 2. pH levels at reference site 3 were neutral. Samples from site 1 and 2 were highly turbid whereas the turbidity for site 3 normal and under the ZINWA Blue limit (range $\leq 5$ NTU). The mean values for conductivity in sites 1 and 2 were in the ZINWA Red category (range $\leq 3500 \mu \mathrm{Scm}^{-1}$ ) whilst those from site 3 comply with the Blue permit range of $\leq 200 \mu \mathrm{Scm}^{-1}$.

\subsection{Biological assessment of water quality}

\subsubsection{Composition and spatial variation of benthic invertebrates}

Between April and December 2009, benthic invertebrate fauna from 12 taxonomic orders were collected from Mazai stream. The most abundant taxa in terms of relative frequency were Hemiptera $>40 \%$ at site 3 followed by Chironomidae $(>24 \%$ at sites $1 \& 2$ ) and Oligochaeta (19\% at site 2) (Table 2). Rare taxa included Nematoda, Megaloptera and Plecoptera whose relative frequencies were less than $4 \%$. Highest diversity of taxa was at site $3\left(\mathrm{H}^{\prime}=1.5\right)$ compared to sites 1 and $2\left(\mathrm{H}^{\prime}=1.25 \& \mathrm{H}^{\prime}=1.39\right)$ respectively (Table 3$)$. The evenness of distribution of pollution sensitive taxa was low at site $3(\mathrm{E}=0.6)$ compared to pollution tolerant taxa at sites 1 and $2(\mathrm{E}=0.9 \& \mathrm{E}=0.8)$ respectively.

The first two axis of the DCA ordination accounted for most of the variation in the species data with eigen values of 0.47 and 0.09 for axis 1 and 2 respectively. The first two axis explained $59.6 \%$ of the total variation. The gradient length was 1.73 and 0.99 for these axes. The first axis thus corresponds to the most important gradient in the species data. It reflects variation in species amongst the three sites. Site 3 was dominated by pollution sensitive taxa (Hemiptera, Trichoptera. Coleoptera and Plecoptera) whilst sites 1 and 2 were dominated by pollution tolerant taxa (Simulidae, Chironomidae, Hirudenea and Oligochaeta) (Figure 2).

3.2.2 SASS score as indicator of water quality

The SASS4 score at site 1 was 10 and the ASPT was 2.5 indicating a major deterioration in water quality. The SASS4 score at site 2 was 25 and the ASPT was 4.17 also showing major deterioration in water quality. This was in contrast to site 3 where the SASS4 score was 134 and ASPT was 13.4 showing good water quality (Table 3).

\section{Discussion}

According to Chutter (1998), there is major deterioration in water quality in Mazai stream after the industrial 
effluent discharge sites. Physico-chemical parameters were relatively high at sites 1 and 2 compared to site 3 indicating high pollution levels. Industrial effluents contributed a relatively high percentage of pollutants in Mazai stream. High ammonia levels were noted at sites 1 and 2. The $\mathrm{NH}_{3}-\mathrm{pH}$ equilibrium contributed to low diversity of macro-invertebrates at these sites. It has been established that the toxic effect of ammonia is directly related to the concentration of the unionized form (Moyo and Worster, 1997; Camargo et al., 2005). In its normal state ammonia has little or no effect on aquatic life forms. Ammonia exists either in the ionized form $\left(\mathrm{NH}_{4}{ }^{+}\right)$or the unionized form $\left(\mathrm{NH}_{3}\right)$. Fish kills in Lake Chivero in 1996 before the turnover period were mainly due to ammonia toxification of water bodies which has exactly the same effects on other aquatic life forms such as macro-invertebrates (Magadza, 1997; Moyo, 1997). The ammonia values at sites 1 and 2 are in the Red permit classification indicating poor water quality whereas that of site 1 complies with the Blue permit indicating safe water quality (Statutory Instrument, 2007). Phosphate levels were extremely high at site 1 almost twice the value at site 2 which is also classified under the Red category (Statutory Instrument, 2007).

The overall water quality through assessment by physico-chemical parameters were in the Blue range at site 3 compared to the Red classification of sites 1 and 2. The results obtained through chemical analysis of Mazai stream are directly related to those derived from the SASS4 scoring. Higher diversity of pollution tolerant species such as chironomids, nematodes, Simuliidae and the leeches dominated sites 1 and 2. These organisms are able to survive under extreme toxic pollutant conditions including low oxygen levels (Micheal and Kelso, 2007). The environment at site 1 is inhospitable since pollutant tolerant macro-invertebrates were also showing very low species richness. Site 2 was also dominated with pollutant tolerant organisms though there is resurgence of moderately sensitive macro-invertebrates. This might possibly be a result of dilution effect from site 3 which contributes clean water into Mazai stream and the self purification process (Machena, 1997). The macro-invertebrates from site 3 included Trichoptera, and Plecoptera which are strictly freshwater species with high susceptibility to toxic pollutant, inorganic pollutants and anoxic conditions (Allan, 1995). Their presence indicates good water quality implying that it is actually possible to maintain Mazai stream in good condition if strict measures are exercised on effluent disposal.

High oxygen is required to oxidize the inorganic pollutants at site 1 as shown by the high permanganate value. The final on macro-invertebrates is that it tends to reduce macro-invertebrate diversity at these sites. The permanganate value lies in the Blue permit range at site 3 which is confirmed by the SASS score obtained. Sites 1 and 2 show an assemblage of macro-invertebrates from the low oxygen tolerant group to the moderately low oxygen tolerant species (Connolly et al., 2004).

Mazai stream eventually discharges into Umguza dam. High phosphates and nitrates levels may contribute to the eutrophication of Umguza dam (Ndebele, 2009). Regulating effluent discharge from the industries and sewage works will significantly reduce the risk of pollution at Umguza dam. The accumulation rate of these nutrients will continue than it can be naturally controlled through the self purification process. The distance from the discharge sites to Umguza dam is less than 10 kilometers implying that it is difficult for self purification of Mazai stream to be effected (Yoshida \& Yasui, 1992; Machena, 1997; Mehrdadi et al., 2006). This is a result of high accumulation rates coupled with diffuse cases of sewage leakages from the sorrounding residential areas Makhokhoba, Mzilikazi,Trenance and Richmond.

The nutrient concentrations will continue to rise as the volume of sewage effluent increases caused by increasing population density in the city and the need to increase the production in the industrial areas. Strict measures should be exercised by the local authority to ensure that industrial effluent discharged into streams is treated. There is also a need to revise penalties for the different ZINWA categories so as to discourage pollution by industrialists.

\section{References}

Allan, J.D. (1995). Stream ecology of running waters. Kluwer Academic Publishers, London, UK

Carmago, J A, Alonso, A., Salamanca, A. (2005) Nitrate toxicity to aquatic animals: a review with new data for freshwater invertebrates. Chemosphere, 58,1255- 1267.

Chutter, F.M. (1972). An impirical biotic index of the quality of water in South African streams and rivers. Water Research, 6:16

Chutter, F.M. (1994). The Rapid biological assessment of Stream and River water quality by means of Macro invertebrate community in South Africa: Progress Report to the Water Research Commission, Pretoria, South Africa.

Chutter, F.M. (1998). Research on the Rapid Biological Assessment of Water Quality Impacts in Streams and Rivers. Report to the Water Research Commission by Environmental CSIR. WRC Report No 422/1/98. Pretoria

Connolly, N.M., Crossland, M.R., Pearson, R.G.. (2004). Effects of low dissolved oxygen on survival, emergence and drift of tropical stream macroinvertebrates. Journal of the North American Bentholgoical Society, 23, 251 270.

Hill, M.O. and Gauch, H.G.. (1980). Detrended correspondence analysis: an improved ordination technique. Vegetatio, $42,47-58$. 
Machena, C. (1997). The self purification capacity of the Mukuvisi river. In N.A.G Moyo (Eds) Lake Chivero, a polluted lake. University of Zimbabwe Publications, Harare, Zimbabwe.

Magadza, C.H.D. (1997). Water pollution and catchment management of in Lake Chivero. In N.A.G Moyo (Eds) Lake Chivero, a polluted lake. University of Zimbabwe Publications, Harare, Zimbabwe.

Magadza, C. H. D. (2003). Lake Chivero: a management case study. Lakes Reservors. Research. Management, 8, 69-81.

Mathuthu, A.S., Mwanga, K. and Simoro, A. (1997). Impact Assessment of Industrial and Sewage Effluents on Water Quality of the receiving Marimba River in Harare. In N.A.G Moyo (Eds) Lake Chivero, a polluted lake. University of Zimbabwe Publications, Harare, Zimbabwe.

Mehrdadi, M. G., Nasrabadi, T., Hoveidi, H., (2006) Evaluation of the quality and self purification potential of Tajan river using QUALZE Model. Iran Journal of Environment. Health. Science . Engineering, 3, 199 - 204.

Michael, D.K., and Kelso, E.W. (2007). Association of macro-invertebrates assemblages with dissolved oxygen concentration and woody surface area in selected subtropical streams of the southern USA. Aquatic Ecology, 41, $95-110$.

Moyo, N.A.G. (1997). Causes of massive fish deaths in Lake Chivero. In N.A.G Moyo (Eds) Lake Chivero, a polluted lake. University of Zimbabwe Publications, Harare, Zimbabwe.

Moyo, N.A.G. and Worster, K. (1997). The effects of Organic Pollution on the Mukuvisi River. In N.A.G Moyo (Eds) Lake Chivero, a polluted lake. University of Zimbabwe Publications, Harare, Zimbabwe.

Ndebele, R.M. (2009). Primary production and other limnological aspects of Cleveland dam, Harare, Zimbabwe. Lakes \& Reservoirs: Research and Management, 14,151-161.

Past (1999 - 2009). PAleontological STatistics, version 1.95. Reference manual, Natural History Museum, University of Oslo

Statutory Instrument (2007). Effluent and Solid Waste Disposal Regulations. Government publishers, Harare, Zimbabwe.

Yoshida, I. and Yasui, T. (1992). Studies on the self purification of rivers. Bull. Fac. Agric.Tottori Uni 45, $33-$ 38.

\section{Tables}

Table 1. Mean values ( \pm standard deviation) of chemical and physical parameters of water from Mazai stream

\begin{tabular}{lrrr}
\hline Parameter & Site 1 & Site 2 & Site 3 \\
\hline Ammonia $\left(\mathrm{mgL}^{-1}\right)$ & $21.94 \pm 1.81$ & $8.16 \pm 2.22$ & $0.01 \pm 0$ \\
Nitrate $\left(\mathrm{mg} \mathrm{L}^{-1}\right)$ & $1.40 \pm 0.5$ & $2.07 \pm 1.5$ & $0.09 \pm 0.01$ \\
PV $\left(\right.$ Absorbed $\left.{ }_{2} \mathrm{mg} \mathrm{L}^{-1}\right)$ & $63.33 \pm 9.24$ & $36.00 \pm 6.93$ & $4.00 \pm 2$ \\
Phosphate $\left(\mathrm{mgL}^{-1}\right)$ & $11.62 \pm 6.32$ & $6.75 \pm 0.56$ & $0.97 \pm 1.11$ \\
Conductivity $\left(\mathrm{mScm}^{-1}\right)$ & $89.67 \pm 1.81$ & $81.00 \pm 7.2$ & $53.67 \pm 3.06$ \\
pH (units) & $6.83 \pm 0.12$ & $7.30 \pm 0.26$ & $7.03 \pm 0.06$ \\
Temperature $\left({ }^{\circ} \mathrm{C}\right)$ & $22.0 \pm 2.89$ & $25.33 \pm 0.58$ & $23.00 \pm 0$ \\
Turbidity (NTU) & - & - & $0.1 \pm 0$ \\
\hline
\end{tabular}

Table 2. Total number (n) and percentage (\%) of benthic macro-invertebrates caught at the 3 sites in Mazai stream

\begin{tabular}{|c|c|c|c|c|c|c|}
\hline \multirow[t]{2}{*}{ Taxon } & \multicolumn{2}{|c|}{ Site 1} & \multicolumn{2}{|c|}{ Site 2} & \multicolumn{2}{|c|}{ Site 3} \\
\hline & $\mathrm{n}$ & $\%$ & $\mathrm{n}$ & $\%$ & $\mathrm{n}$ & $\%$ \\
\hline Coleoptera & 0 & 0 & 0 & 0 & 4 & 6.9 \\
\hline Decapoda & 0 & 0 & 0 & 0 & 3 & 5.2 \\
\hline Chironomiidae & 6 & 40 & 7 & 41.2 & 0 & 0.0 \\
\hline Dixidae & 0 & 0 & 0 & 0 & 3 & 5.2 \\
\hline Simuliidae & 4 & 26.7 & 1 & 5.9 & 0 & 0.0 \\
\hline Gastropoda & 0 & 0 & 2 & 11.8 & 0 & 0.0 \\
\hline Hemiptera & 0 & 0 & 0 & 0 & 30 & 51.7 \\
\hline Hirudinea & 4 & 26.7 & 0 & 0 & 0 & 0.0 \\
\hline Megaloptera & 0 & 0 & 0 & 0 & 1 & 1.7 \\
\hline Nematoda & 1 & 6.7 & 0 & 0 & 0 & 0.0 \\
\hline Odonata & 0 & 0 & 2 & 11.8 & 11 & 19.0 \\
\hline Oligochaeta & 0 & 0 & 5 & 29.4 & 0 & 0.0 \\
\hline Plecoptera & 0 & 0 & 0 & 0 & 1 & 1.7 \\
\hline Trichoptera & 0 & 0 & 0 & 0 & 5 & 8.6 \\
\hline & 15 & & 17 & & 58 & \\
\hline
\end{tabular}


Table 3. SASS4 score, diversity (H') and eveness (E) of benthic macro-invertebrates in Mazai stream

\begin{tabular}{clllll}
\hline Sampling Site & SASS4 Score & Number of Families & ASPT & $\mathbf{H}^{\mathbf{1}}$ & E \\
\hline 1 & 10 & 4 & 2.5 & 1.25 & 0.8 \\
2 & 25 & 5 & 4.17 & 1.39 & 0.8 \\
3 & 134 & 8 & 13.4 & 1.52 & 0.6 \\
\hline
\end{tabular}

Figures

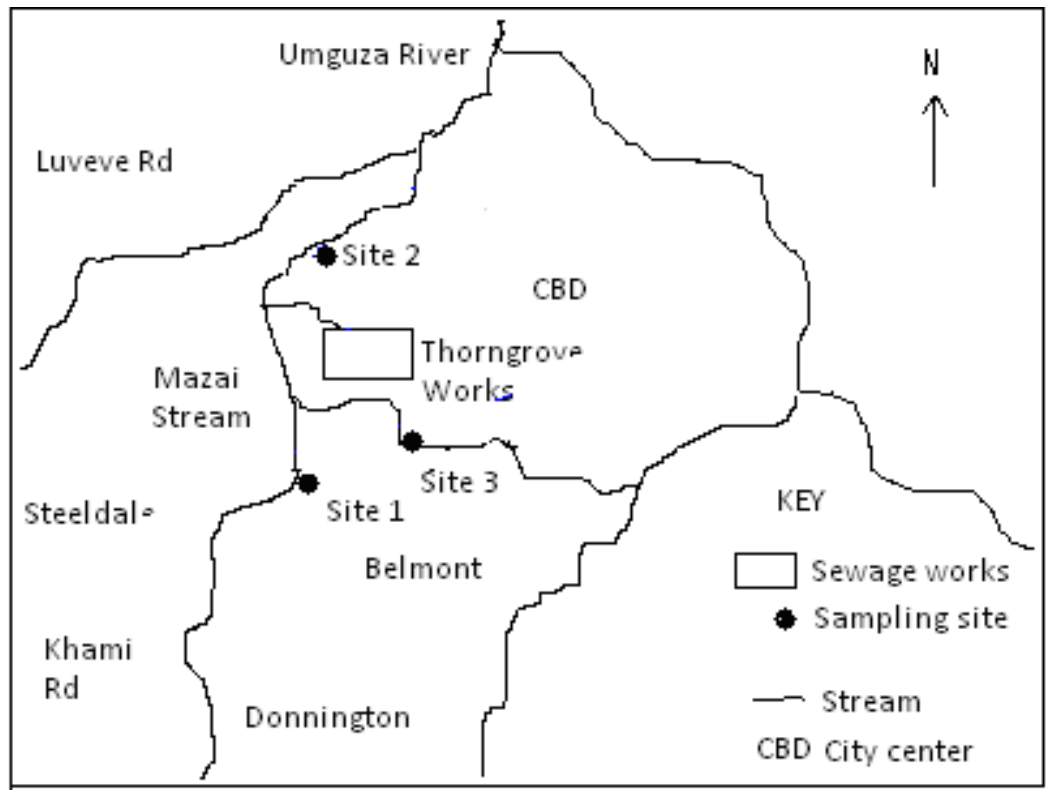

Figure 1. Map showing sampling sites in Mazai stream

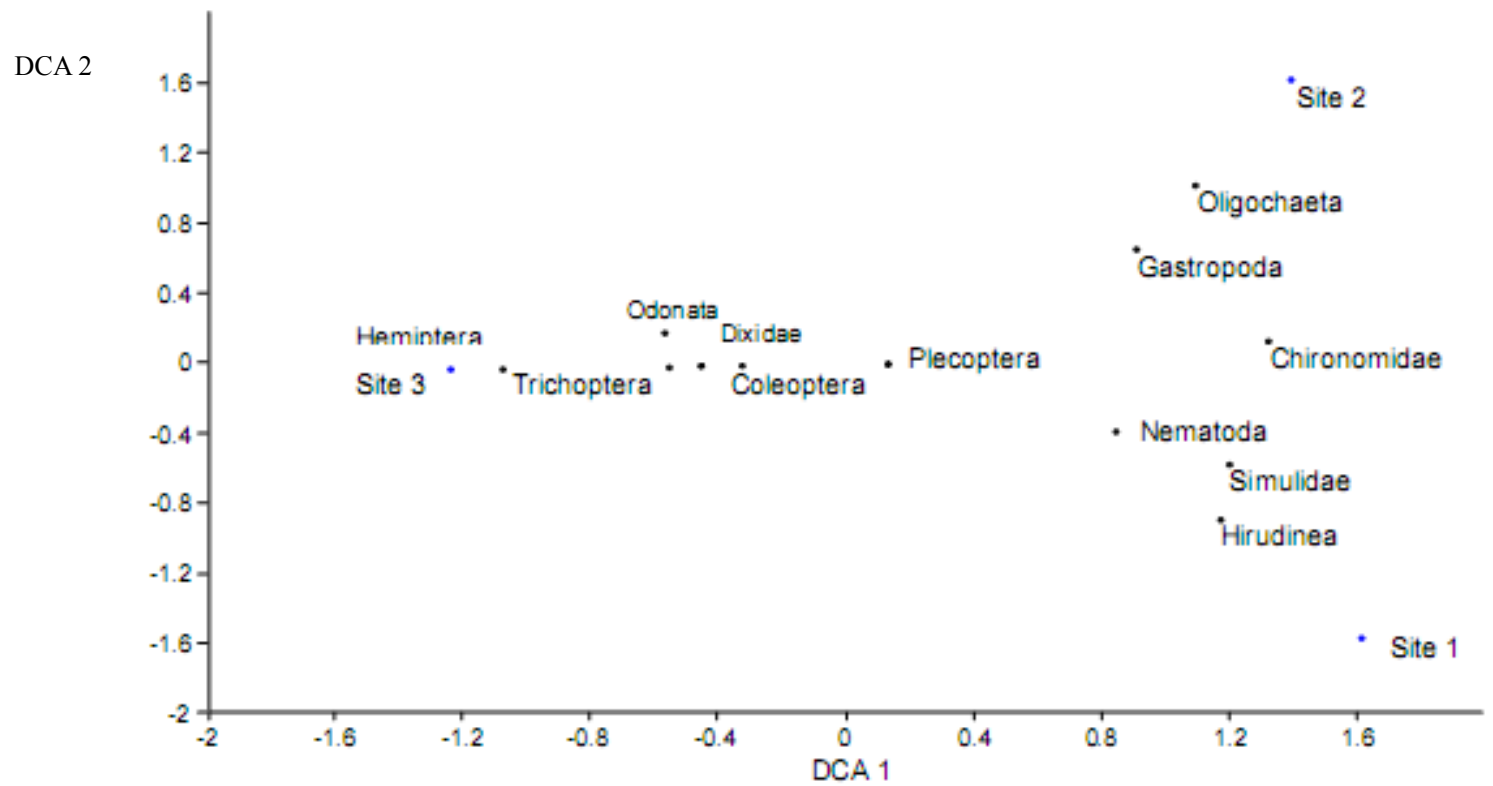

Figure 2. DCA ordination of macro-invertebrate samples in Mazai stream 